\title{
ANALISIS KEMAMPUAN KOGNITIF DAN SIKAP SISWA PADA MATERI SISTEM REPRODUKSI MANUSIA KELAS XI IPA SMA NEGERI 1 TANJUNG MORAWA T.P 2016/2017
}

\author{
Jessika Rajagukguk ${ }^{*}$, Ashar Hasairin, Nurhayati Hutagaol \\ ${ }^{1}$ Program Studi Pendidikan Biologi, FMIPA, Universitas Negeri Medan, Medan JI. Willem Iskandar Psr. V Medan Estate, Medan, \\ Indonesia, 20221 \\ 2 Jurusan Biologi, FMIPA, Universitas Negeri Medan, Medan Jl. Willem Iskandar Psr. V Medan Estate, Medan, Indonesia, 20221 \\ ${ }^{3}$ SMA N 1 Tanjung Morawa, Jl Batang Kuis Pasar VII, Tanjung Morawa 20354 \\ *E-mail : jessikarajagukguk95@gmail.com
}

\begin{abstract}
ABSTRAK
Penelitian ini bertujuan untuk mengetahui kemampuan pengetahuan dan sikap siswa pada materi sistem reproduksi manusia di kelas XI IPA dari aspek kognitif dan sikap siswa di kelas XI SMA Negeri 1 Tanjung morawa Tahun Pembelajaran 2016/2017. Populasi yang digunakan seluruh siswa kelas XI IPA sebanyal 78 orang. 39 sampel diambil secara purposive sampling di kelas XI IPA 5 dan 39 sampel lainnya dari diambil secara purposive sampling di kelas XI IPA 6. Data dikumpulkan dari lembar observasi untuk mengetahui sikap siswa dan 30 soal untuk mendapatkan hasil belajar siswa. Hasil penelitian menunjukkan bahwa nilai kemampuan aspek kognitif siswa tergolong kategori baik dengan nilai rata-rata 72,08. Persentasi kemampuan siswa dalam menjawab soal tiap indikator dapat dijabarkan sebagai berikut: indikator mengidentifikasi stuktur dan fungsi sistem reproduksi 52\%, indikator menjelaskan proses yang terjadi dalam sistem reproduksi $49 \%$, dan indikator untuk menjelaskan tentang kesehatan reproduksi 48\%. Sementara untuk nilai sikap siswa tergolong kategori baik dengan nilai rata-rata 70,76 . Persentasi penilaian sikap siswa terdiri dari 5 kategori dapat dijabarkan sebagai berikut : persentasi sikap menghormati $80,68 \%$, persentasi sikap tanggung jawab 75,08\%, persentasi sikap displin sebanyak $81,97 \%$, persentasi sikap bekerja sama 70,35\% dan persentasi sikap keaktifan 60,81\%.
\end{abstract}

Kata kunci : kemampuan aspek kognitif, sikap siswa, sistem reproduksi manusia

\section{ABSTRACT}

This study aims of the research were to find the learning outcome and attitudes on material of humans reproductive system in class XI IPA SMA Negeri 1 Tanjung morawa Learning Year 2016/2017. The population in this study were all students of class XI IPA which amounted to 78 people. 39 samples taken by purposive sampling in class XI IPA 5 and 39 samples from each classes were taken by purposive sampling. The datas were collected by observasion sheets were used to know students attitudes and 30 question were used to get learning outcome the student The results showed that the percentage of cognitive aspect ability was good with the average score of 72,08 . This can be seen from the presentation of the complete value of $75.64 \%$ with the categories of material and unfinished presentation as much as $24.53 \%$ with less understood category. While the presentation of student attitudes is good where the material assessment consisting of the following 5 categories of assessment indicators can be elaborated as follows: presentation of attitudes value to respect as much as $80.68 \%$, presentation of attitudes value for responsibilities of $75.08 \%$, presentation of values Attitudes for discipline as much as $81.97 \%$, presentation attitudes to work together as much as $70.35 \%$ and presentation of attitude values for liveliness as much as $60.81 \%$.

Keywords: cognitive aspect ability, student attitudes, human reproductive system.

\section{PENDAHULUAN}

Manusia mengalami tahap pertumbuhan dan perkembangan dalam siklus kehidupannya. Pertumbuhan dimaksudkan pada pertambahan ukuran badan dan fungsi fisik. Sedangkan perkembangan mengacu pada sifat berkait dengan gejala psikologis, misalnya kemampuan berpikir dan tingkat emosi. Salah satu fase yang dialami oleh manusia adalah masa pubertas yang berlangsung selama kurang lebih 8 - 10 tahun berkisar pada usia 11 - 20 tahun. Fase ini disebut juga sebagai fase remaja. Beberapa tanda dimulainya masa ini adalah adanya perubahan fisik, naluri, dan interaksi sosial.

Masa remaja adalah masa yang paling kritis bagi 
perkembanganya dan mendapatkan sering terjadi kendala. Dimana kendala utama sebagai masa remaja adalah perubahan yang sangat pesat secara fisik maupun psikologisnya. Perubahan fisik yang terjadi pada remaja timbul karena proses perkembangan dan pematangan fungsi dari sistem reproduksi. Perkembangan dan pematangan fungsi dari sistem reproduksi akan memicu aktifnya organ-organ dan hormonal reproduksi.

Dengan aktif dan berfungsinya organ-organ reproduksi dan hormonal dalam diri seorang remaja maka perlu dipahami bagaimana perkembangan dan pemeliharaan alat dan sistem reproduksi. Remaja perlu mengetahui bahwa jika sistem reproduksi sudah berfungsi, maka remaja sudah dapat bereproduksi sebagai seorang dewasa normal. Organ reproduksi dikatakan berfungsi apabila ditandai ditandai dengan haid pada wanita dan mimpi basah pada pria dan tanda-tanda seksual sekunder yang tumbuh (Sarwono, 1997).

Untuk itu, remaja harus memahami organ-organ reproduksi remaja sendiri. Berdasarkan tugas perkembangan remaja, yaitu menerima keadaan fisik dan mempergunakannya secara efektif. Dimana mencakup bahwa remaja harus mengerti dari prinsipprinsip reproduksi yang meliputi menstruasi, kehamilan, proses melahirkan, memelihara diri agar tetap tampil rapi dan bersih, bertingkah laku sopan dalam menjaga diri, dan menghindari hubungan seksual sebelum menikah (Maryanti, 2009).

Kenyataannya remaja menghadapi kebingungan dengan apa yang dialami. Hal ini dapat menimbulkan masalah besar pada diri remaja. Menurut Febry, dkk (2012) bahwa jumlah remaja umur 10-19 tahun di Indonesia terdapat 43 juta atau 19,61\% dari jumlah penduduk Indonesia sebanyak 220 juta. Sekitar 1 juta remaja pria (5\%) dan 200 ribu remaja wanita (1\%) menyatakan secara terbuka bahwa pernah melakukan hubungan seksual. Sebanyak 8\% pria umur 15-24 tahun telah menggunakan obat-obatan terlarang. Sedangkan untuk kasus HIV/AIDS dari 6987 penderita AIDS, 3,02\% adalah kelompom usia 15-19 tahun dan $54,77 \%$ adalah kelompok usia 20-29 tahun Ini terjadi karena pengetahuan dan sikap siswa dalam menangani kesehatan reproduksinya masih kurang.
Sehingga sangat memerlukan perhatian bagi semua pihak termasuk salah satunnya seorang guru dan sekolah

Menurut Maolinda, dkk (2008) bahwa kondisi sistem reproduksi yang sangat penting ini mendorong pusat informasi kesehatan reproduksi remaja (PIK-R) menjadi program nasional pada tahun 2000. SMAN 1 Tanjung morawa merupakan salah satu sekolah yang ada di Medan. Dimana sekolah ini terdapat pusat informasi kesehatan reproduksi yang sudah berdiri sejak 2012. Pusat informasi kesehatan reproduksi remaja (PIK-R) ini aktif sebagai pusat informasi pada sekolah ini yang dijalankan langsung oleh siswa sekolah ini sendiri.

Berdasarkan observasi yang sudah dilakukan peneliti dengan memberikan soal pilihan ganda untuk mengukur kemampuan kognitif di SMA Negeri 1 Tanjung morawa, ternyata siswa belum memenuhi Standar Ketuntasan Belajar Mengajar yaitu 70 pada mata pelajaran Biologi pada semester II di kelas XII Tahun Pelajaran 2016/2017. Nilai rata-rata yang diperoleh siswa yang diperoleh hanya 68. Rata-rata nilai ini sama sekali belum mencapai nilai standar ketuntasan belajar. Sementara untuk mengukur sikap siswa sendiri, peneliti melakukan wawancara kepada perwakilan kelas X-XII, dimana ada 12 orang siswa yang menyatakan sikap menolak karena merasa malu dan risih membahas mengenai materi sistem reproduksinya sedangkan 20 orang siswa lainnya menyatakan menerima karena dengan mempelajari tentang sistem reproduksi akan menambah pengetahuannya dan memikirkan cara untuk menjaga organ reproduksinya dari berbagai hal buruk.

Hal ini menunjukkan bahwa adanya keragaman mengenai pengetahuan dan sikap siswa mengenai materi sistem reproduksi. Untuk itu, sangat penting pada kaum muda perlu menambah pengetahuan dan sikap menolak diri untuk terjerumus pada hal buruk khususnya pada siswa remaja dapat terhindar dari kehamilan yang tidak diinginkan, terlindung dari infeksi menular seksual (IMS) dan dapat tumbuh menjadi orang dewasa yang sehat secara seksual. Berdasarkan uraian latar belakang di atas peneliti tertarik untuk melakukan penelitian mengenai "Analisis Kemampuan Kognitif dan Sikap Siswa Pada 
Materi Sistem Reproduksi Manusia di Kelas XI IPA SMA Negeri 1 Tanjung morawa Tahun Pembelajaran 2016/2017".

\section{METODE PENELITIAN}

Lokasi penelitian ini adalah di Sekolah SMA Negeri 1 Tanjung Morawa yang beralamat di Jl. Batang Kuis Pasar VIII Tanjung Morawa, Deli Serdang. Waktu penelitian ini dilaksanakan pada bulan Mei - Juni 201. Populasi dalam penelitian ini adalah seluruh siswa di kelas XI IPA SMA Negeri 1 Tanjung Morawa yang terdiri dari 6 kelas yaitu : XI IPA ${ }_{1}, X_{I} I_{2}, A_{2}$ XI IPA ${ }_{3}, X I$ $I_{\text {IPA }}$, XI IPA 5 , XI IPA 6 . Sampel yang digunakan dalam penelitian ini adalah kelas XI IPA 5 dan XI IPA 6. Dalam penelitian ini pengambilan sampel dilakukan secara purposive sampling. Penelitian ini merupakan penelitian deskriptif yang berupaya untuk mendeskripsikan kemampuan kognitif dan sikap siswa pada materi sistem reproduksi manusia. Sumber data dalam penelitian ini diperoleh dari lembar observasi sikap yang dilakukan oleh observer untuk mengukur sikap pada materi sistem reproduksi manusia. Memberikan tes kognitif dalam bentuk soal-soal pilihan ganda untuk mengukur kemampuan kognitif siswa pada materi sistem reproduksi manusia. Instrument data yang digunakan dalam penelitian ini adalah tes soal pilihan ganda untuk menilai kemampuan kognitif dan lembar observasi sikap siswa untuk penilaian sikap siswa.

\section{HASII PENELITIAN}

Pada bagian ini akan diuraikan secara terperinci mengenai hasil penelitian untuk menghitung kemampuan kognitif dan sikap siswa pada materi sistem reproduksi manusia di kelas XI IPA SMA Negeri 1 Tanjung morawa. Data penelitian ini diperoleh berdasarkan jawaban siswa terhadap soal dan penilaian observasi yang dilakukan oleh peneliti pada siswa yang berjumlah 78 orang siswa.

\section{Kemampuan Kognitif}

Berdasarkan hasil penelitian pada jumlah sampel sebanyak 78 orang siswa maka diperoleh nilai ratarata adalah 72,08 ( Pada Lampiran 16). Hasil penelitian ini diperoleh berdasarkan tingkat kemampuan kognitif siswa dalam menjawab soal yang diujikan. Soal diberikan kepada siswa saat sudah menyelesaikan pembelajaran pada materi sistem reproduksi manusia.

Dari hasil tes yang telah dilakukan menunjukkan bahwa tingkat penguasaan siswa pada materi sistem reproduksi manusia masih jauh dari nilai KKM, jumlah siswa yang menjawab benar dari aspek kognitif maupun dari setiap indikator tidak ada yang mencapai 85\%, artinya dari kedua aspek tersebut dikatakan tidak tuntas secara klasikal, dapat dilihat pada Tabel 1.

Tabel 1. Kemampuan Siswa Menjawab Soal Berdasarkan Aspek Kognitif

\begin{tabular}{|c|c|c|c|c|c|c|}
\hline \multirow[b]{2}{*}{ No } & \multirow[b]{2}{*}{$\begin{array}{l}\text { Aspek } \\
\text { Kognitif }\end{array}$} & \multirow[b]{2}{*}{$\begin{array}{l}\text { No } \\
\text { Soal }\end{array}$} & \multicolumn{3}{|c|}{ Jumlah Seluruh Siswa } & \multirow[b]{2}{*}{$\begin{array}{c}\text { Rata-rata } \\
\text { menjawab } \\
\text { benar (\%) }\end{array}$} \\
\hline & & & $\begin{array}{c}\text { Jumlah siswa } \\
\text { menjawab } \\
\text { benar }\end{array}$ & $\begin{array}{c}\text { Jumlah siswa } \\
\text { menjawab } \\
\text { salah }\end{array}$ & $\begin{array}{c}(\%) \text { Siswa } \\
\text { menjawab } \\
\text { benar }\end{array}$ & \\
\hline \multirow{5}{*}{1.} & \multirow{5}{*}{$\begin{array}{l}\text { Pengetahuan } \\
\text { (C1) }\end{array}$} & 2 & 44 & 34 & $56 \%$ & \multirow{5}{*}{$52 \%$} \\
\hline & & 8 & 36 & 42 & $46 \%$ & \\
\hline & & 23 & 37 & 41 & $47 \%$ & \\
\hline & & 26 & 40 & 38 & $51 \%$ & \\
\hline & & 29 & 47 & 31 & $60 \%$ & \\
\hline \multirow{4}{*}{2.} & \multirow{4}{*}{$\begin{array}{l}\text { Pemahaman } \\
\text { (C2) }\end{array}$} & 1 & 58 & 20 & $74 \%$ & \multirow{4}{*}{$60 \%$} \\
\hline & & 11 & 41 & 37 & $52 \%$ & \\
\hline & & 12 & 38 & 40 & $48 \%$ & \\
\hline & & 24 & 53 & 25 & $67 \%$ & \\
\hline \multirow{4}{*}{3.} & \multirow{4}{*}{$\begin{array}{l}\text { Penerapan } \\
\text { (C3) }\end{array}$} & 5 & 53 & 25 & $67 \%$ & \multirow{4}{*}{$57 \%$} \\
\hline & & 14 & 37 & 41 & $47 \%$ & \\
\hline & & 15 & 40 & 38 & $51 \%$ & \\
\hline & & 18 & 60 & 18 & $76 \%$ & \\
\hline
\end{tabular}




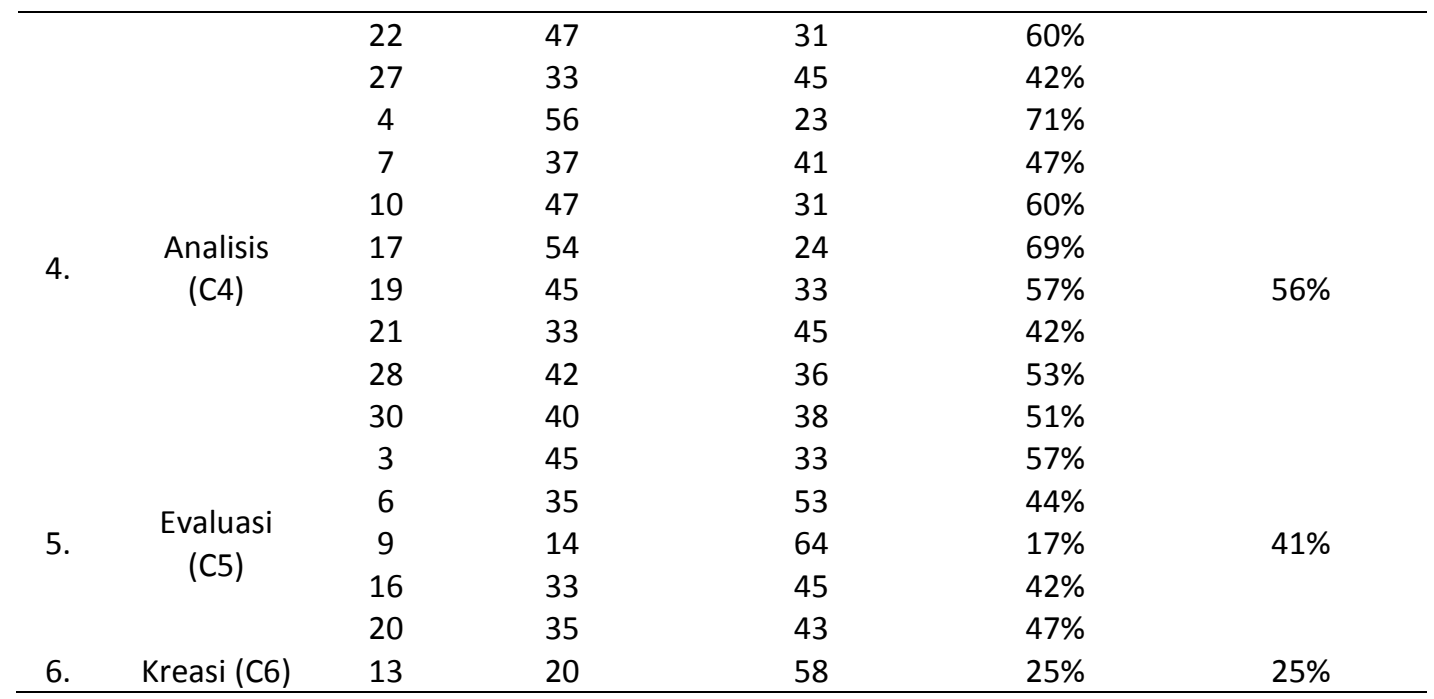

Untuk lebih jelasnya dapat dilihat pada gambar 4.1 yang menunjukkan persentase kemampuan dalam menjawab soal kelima indikator kognitif.

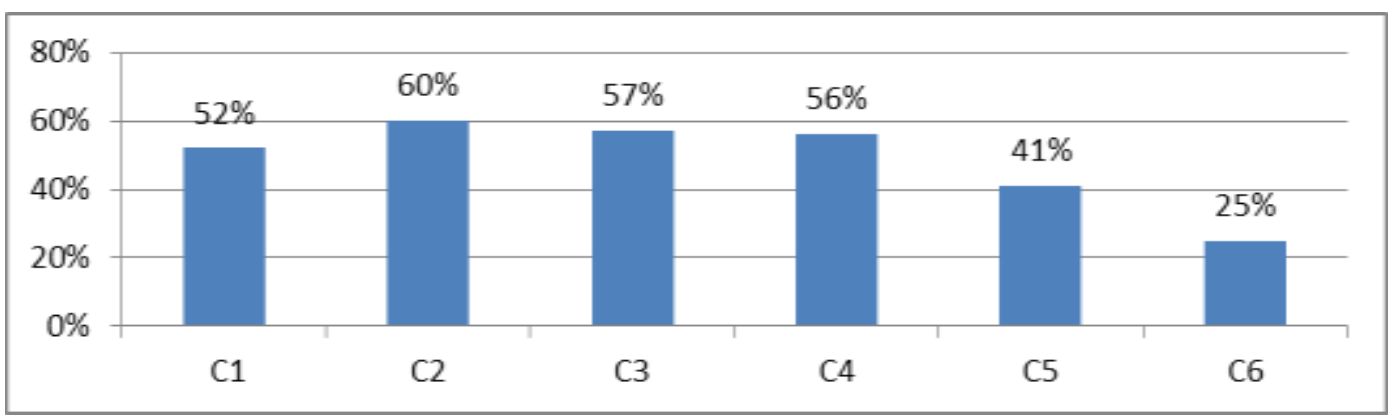

Gambar 1. Persentase Kemampuan Kognitif Siswa

Dari data pada Gambar 1 dijelaskan bahwa banyak siswa yang menjawab soal dengan C1, C2, C3, dan C4 sementara sisanya sedikit siswa yang menjawab soal C5 dan C6. Hal ini dikarenakan bahwa kemampuan siswa pada saat menjawab soal yang menyangkut mengenai pengetahuan, pemahaman, dan penerapan dan analisis cukup mudah bagi siswa dibanding untuk menjawab soal yang menyakut mulai dari sintesis dan evaluasi memungkinkan siswa untuk sulit menjawab pertanyaan karena tingkatan soal C5, dan C6 merupakan contoh soal dengan tingkatan soal yang tinggi. Sementara untuk melihat kemampuan siswa dalam menjawab soal yang benar pada tiap indikatornya dapat dilihat pada Tabel 2.

Tabel 2. Analisis Kebenaran Siswa Dalam Menjawab Soal Pada Tiap Indikator

\begin{tabular}{|c|c|c|c|c|c|}
\hline \multirow[t]{2}{*}{ NO } & \multirow{2}{*}{$\begin{array}{c}\text { Indikator } \\
\text { Pembelajaran }\end{array}$} & \multirow[t]{2}{*}{ Nomor soal } & \multicolumn{2}{|c|}{ Jumlah seluruh siswa } & Persentasi \\
\hline & & & Jumlah siswa & (\%) siswa & Total Tiap \\
\hline
\end{tabular}




\begin{tabular}{|c|c|c|c|c|c|}
\hline & & & & & \\
\hline & & & $\begin{array}{c}\text { menjawab } \\
\text { benar }\end{array}$ & $\begin{array}{c}\text { menjawab } \\
\text { benar }\end{array}$ & Indikator \\
\hline \multirow[t]{5}{*}{1} & \multirow{5}{*}{$\begin{array}{l}\text { Mengidentifikasi } \\
\text { struktur dan fungsi } \\
\text { sistem }\end{array}$} & 1 & 58 & $74 \%$ & \multirow{5}{*}{$52 \%$} \\
\hline & & 9 & 14 & $17 \%$ & \\
\hline & & 18 & 60 & $76 \%$ & \\
\hline & & 21 & 33 & $42 \%$ & \\
\hline & & 26 & 40 & $51 \%$ & \\
\hline \multirow[t]{13}{*}{2} & \multirow{13}{*}{$\begin{array}{l}\text { Menjelaskan proses } \\
\text { yang terjadi dalam } \\
\text { sistem reproduksi }\end{array}$} & 2 & 44 & $56 \%$ & \multirow{13}{*}{$49 \%$} \\
\hline & & 3 & 45 & $57 \%$ & \\
\hline & & 8 & 36 & $46 \%$ & \\
\hline & & 11 & 41 & $52 \%$ & \\
\hline & & 12 & 38 & $48 \%$ & \\
\hline & & 13 & 20 & $25 \%$ & \\
\hline & & 14 & 37 & $47 \%$ & \\
\hline & & 15 & 40 & $51 \%$ & \\
\hline & & 17 & 33 & $42 \%$ & \\
\hline & & 19 & 45 & $57 \%$ & \\
\hline & & 20 & 35 & $44 \%$ & \\
\hline & & 23 & 37 & $47 \%$ & \\
\hline & & 24 & 53 & $67 \%$ & \\
\hline \multirow[t]{12}{*}{3} & \multirow{12}{*}{$\begin{array}{l}\text { Menjelaskan tentang } \\
\text { kesehatan reproduksi }\end{array}$} & 4 & 56 & $71 \%$ & \multirow{12}{*}{$48 \%$} \\
\hline & & 5 & 53 & $67 \%$ & \\
\hline & & 6 & 35 & $44 \%$ & \\
\hline & & 7 & 37 & $47 \%$ & \\
\hline & & 10 & 47 & $60 \%$ & \\
\hline & & 16 & 48 & $61 \%$ & \\
\hline & & 22 & 47 & $60 \%$ & \\
\hline & & 25 & 21 & $26 \%$ & \\
\hline & & 27 & 33 & $42 \%$ & \\
\hline & & 28 & 42 & $53 \%$ & \\
\hline & & 29 & 47 & $60 \%$ & \\
\hline & & 30 & 40 & $51 \%$ & \\
\hline
\end{tabular}

Untuk lebih jelas dapat dilihat pada diagram berikut ini.

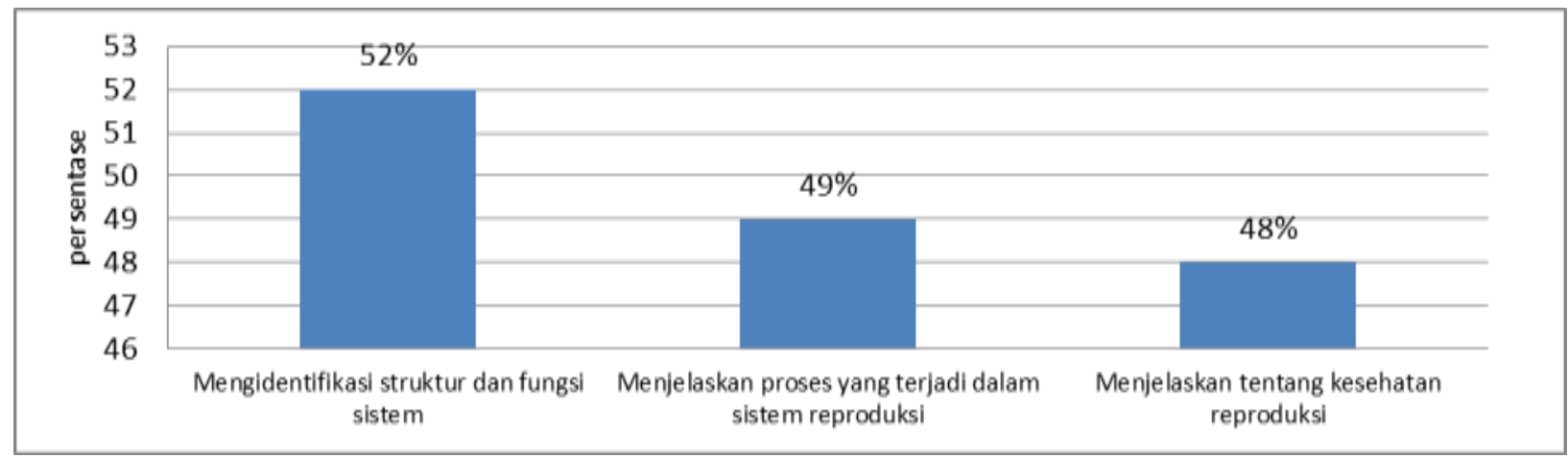

Gambar 2. Persentase Siswa Menjawab Soal Berdasarkan Indikator Pembelajaran

Dari Gambar 2 berikut ini dijelaskan bahwa persentase tertinggi terlihat pada indikator I (mengidentifikasi struktur dan fungsi sistem) yang menjelaskan struktur dan fungsi dari sistem 
reproduksi manusia, hal ini terjadi karena siswa lebih mudah memahami dan menghapal bagian-bagian dari stuktur karena dapat dilihat secara langsung bagaimana bentuk dan lokasinya dalam tubuhnya melalui gambar yang dapat dilihat dari buku ataupun internet.

Sementara untuk indikator II (menjelaskan proses yang terjadi dalam sistem reproduksi) dan III (menjelaskan tentang kesehatan reproduksi) sulit bagi siswa karena dalam memahami dan menjelaskan bagaimana proses yang terjadi dalam sistem reproduksi ini dikarenakan ini menyakut penelaran setiap siswa yang berbeda satu sama lain dalam hal menjelaskan proses dalam sistem reproduksi dan kesehatan reproduksi manusia.
Untuk mengukur sikap siswa maka dilakukan penelitian secara observasi dimana observasi dilakukan selama proses pembelajaran dilaksanakan. Hasilnya dapat dilihat pada tabel (Lampiran 18) dimana bahwa nilai rata-rata yang diperoleh siswa kelas XI IPA SMA Negeri 1 Tanjung morawa adalah 70,76 .

Penilaian ini diperoleh berdasarkan hasil tes observasi yang dilakukan observer selama proses pembelajaran berlangsung pada selama materi sistem reproduksi manusia dilaksanakan. Berdasarkan hal ini dapat disimpulkan penilaian sikap siswa siswa kelas XI IPA 5 dan 6 dinyatakan baik pada saat materi sistem reproduksi manusia dilaksanakan. Untuk lebih jelas dapat dilihat pada diagram berikut ini.

\section{Sikap Siswa}

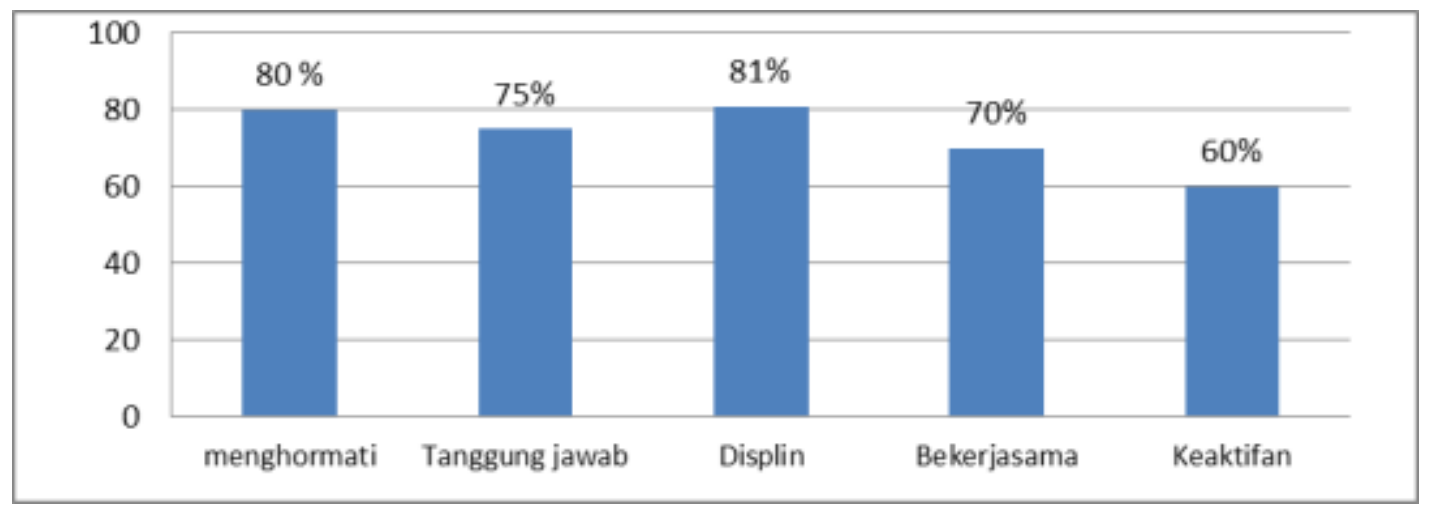

Gambar 3. Persentase Nilai Observasi Sikap Siswa Berdasarkan 5 Aspek Penilaian Sikap

Dari Gambar 3 diatas diketahui bahwa persentase sikap siswa pada 5 aspek indikator dapat dijabarkan sebagai berikut: pada indikator sikap menghormati diperoleh $80,68 \%$, pada indikator sikap tanggung jawab diperoleh 75,08\%, pada indikator sikap displin diperoleh $81,97 \%$, pada indikator sikap bekerja sama diperoleh $70,35 \%$ dan pada indikator sikap keaktifan diperoleh 60,01\%.

Hal ini menunjukkan bahwa sikap siswa nilai sikap siswa paling tinggi terdapat nilai sikap displin dimana ini dikarenakan sikap kedisplin pada siswa masih baik dimana pada penilaian displin aspek yang dinilai yaitu ketepatan masuk kelas, mengumpulkan tugas tepat waktu, mengerjakan tugas yang diberikan dan membawa buku tes mata pelajaran setiap waktunya. Dari aspek pengamatan ini observer menilai semua aspek ini terpenuhi pada semua siswa. Beda halnya dengan beberapa aspek penilaian yang dinilai dari menghormati, bekerja sama, tanggung jawab dan keaktifan yang ditunjukkan oleh siswa selama pengamatan memberikan nilai yang berbeda setiap siswa yang dilihat dari aspek pengamatan yang dilakukan.

\section{PEMBAHASAN}

\section{Kemampuan Kognitif}


Penelitian ini merupakan penelitian deskriptif yaitu penelitian yang dilakukan untuk mengetahui gambaran kemampuan siswa yang dinilai dari kemampuan dasar siswa yaitu kemampuan kognitif. Berdasarkan hasil penelitian yang diperoleh nilai siswa sebesar 70-90 dinyatakan tuntas sementara nilai siswa sebesar 0-60 dinyatakan tidak tuntas. engan rata-rata yang diperoleh yaitu 72,08. Hal ini menyimpulkan bahwa kemampuan kognitif siswa dikategorikan baik. Kemampuan hasil belajar siswa pada materi sistem reproduksi berdasarkan aspek kognitif dideskripsikan sebagai berikut.

Aspek Pengetahuan (C1)

Tingkat kemampuan kognitif siswa tergolong sedang karena dilihat dari rata-rata persentase yang diperoleh siswa pada soal C1 yaitu 52\% sehingga dapat disimpulkan bahwa siswa memiliki konsep pengetahuan awal yang cukup untuk mempelajari materi sistem reproduksi.

Aspek Pemahaman (C2)

Tingkat kemampuan kognitif siswa tergolong tinggi karena dilihat dari rata-rata persentase yang diperoleh siswa pada soal C2 yaitu $60 \%$ sehingga dapat disimpulkan bahwa siswa memiliki konsep pengetahuan awal yang cukup untuk mempelajari materi sistem reproduksi

Aspek Penerapan (C3)

Tingkat kemampuan kognitif siswa tergolong sedang karena dilihat dari rata-rata persentase yang diperoleh siswa pada soal C3 yaitu 57\% sehingga dapat disimpulkan bahwa siswa memiliki konsep yang cukup untuk mempelajari materi sistem reproduksi manusia.

\section{Aspek Analisis (C4)}

Tingkat kemampuan kognitif siswa tergolong sedang karena dilihat dari rata-rata persentase yang diperoleh siswa pada soal C4 yaitu 56\% sehingga dapat disimpulkan bahwa siswa memiliki konsep dan analisa yang cukup dalam memahami materi sistem reproduksi manusia.

Aspek Evaluasi (C5)

Tingkat kemampuan kognitif siswa tergolong sangat rendah karena dilihat dari rata-rata persentase yang diperoleh siswa pada soal C5 yaitu 41\% sehingga dapat disimpulkan bahwa siswa tidak kurang konsep untuk mempelajari materi sistem reproduksi. Pada aspek ini kelemahan siswa semakin tinggi karena konsep yang dimiliki siswa tentang materi sistem reproduksi belum memadai.

Aspek Kreasi (C6)

Tingkat kemampuan kognitif siswa tergolong sangat rendah karena dilihat dari rata-rata persentase yang diperoleh siswa pada soal C6 yaitu $25 \%$ sehingga dapat disimpulkan bahwa siswa sangat kurang dalam memahami dan menalar soal untuk menemukan konsep dalam mempelajari materi sistem reproduksi manusia. Pada aspek C6 ini merupakan aspek kelemahan yang memiliki tingkat kesulitan paling tinggi dibandingkan dengan aspek yang lain.

Berdasarkan penjelasan di atas diketahui bahwa kemampuan kognitif siswa tertinggi terletak pada aspek pemahaman (C2) sebesar 60\%, kemampuan kognitif siswa sedang terletak pada aspek penerapan (C3) yaitu sebesar 57\%, aspek pengetahuan sebesar (C1) 52\%, aspek analisis (C4) sebesar 56\%dan kemampuan kognitif siswa terendah terletak pada aspek evaluasi (C5) dan aspek kreasi (C6) sebesar 25\%.

Dalam proses belajar terdapat usaha yang dilakukan oleh seseorang untuk memperoleh suatu perubahan tingkah laku yang secara keseluruhan sebagai hasil pengalamannya sendiri dalam interaksi dengan lingkungan. Hal ini sesuai dengan pendapat Hamzah (2008) bahwa ada tujuan belajar yang telah diperoleh disini yaitu tercapainya suatu bentuk perubahan didalam diri orang belajar, yaitu adanya perubahan perilaku dari yang tidak tahu menjadi tahu, sehingga diharapkan dengan ilmu atau pengetahuan yang diperoleh oleh semua siswa dapat berguna dan juga dapat diaplikasikan dalam kehidupan sehari.

Menurut Hagerdon (2003) siswa-siswa sekolah saat ini perlu memiliki pengalaman yang baik terhadap resiko dan keuntungan dari mempelajari sistem reproduksi itu sendiri dimana untuk memutuskan secara cerdas penggunaan pengetahuan dalam hal bergaul dan menjaga dari secara benar. Siswa saat ini perlu memiliki pemahaman yang baik terhadap resiko dari yang dipelajari sehingga dapat memutuskan secara tegas penggunaan tersebut dengan benar. 
Beberapa peneliti menunjukkan bahwa adanya hubungan positif antara peningkatan penguasaan dan sikap siswa tentang sistem reproduksi (Sohan, 2003). Dapat dikatakan bahwa apabila seorang siswa telah menguasai dengan benar dan mampu memutuskan secara kritis tentang materi sistem reproduksi maka mereka akan dapat bersikap dengan benar. Oleh karena itu, kemampuan memahami dan menganalisis konsep materi sistem reproduksi manusia haruslah menjadi landasan yang dibekalkan pada siswa (Fadli, 2015)

\section{Observasi Sikap Siswa}

Kelima aspek yang dinilai dari sikap siswa adalah menghormati, tanggung jawab, displin, bekerja sama, dan keaktifan ini merupakan indikator penelitian terhadap proses mengajar dan belajar siswa yang berkaitan dengan materi sistem reproduksi manusia. Diperoleh nilai rata-rata sikap yang dilakukan selama proses pembelajaran sebesar 70,76 yang menunjukkan bahwa sikap siswa pada materi sistem reproduksi ini kategori baik. Sikap siswa pada saat proses pembelajaran pada materi sistem reproduksi berdasarkan beberapa aspek sikap dideskripsikan sebagai berikut.

1. Sikap Menghormati

Nilai sikap menghormati pada aspek yang diamati observer selama proses pembelajaran yaitu menghormati pendapat teman, menerima kesepakatan, menerima kekurangan teman, dan menghormati beda suku dan ras tergolong tinggi karena dilihat dari rata-rata persentase yang diperoleh siswa yaitu $80 \%$ sehingga dapat disimpulkan sikap menghormati pada diri siswa baik dan terjaga kerabatannya.

2. Sikap Tanggung Jawab

Nilai sikap tanggung jawab pada aspek yang diamati observer selama proses pembelajaran yaitu melaksanakan tugas, menerima resiko dari tindakan, tidak menuduh orang lain, dan meminta maaf sedang karena dilihat dari rata-rata persentase yang diperoleh siswa yaitu $75 \%$ sehingga dapat disimpulkan sikap tanggung jawab setiap individu yang ada pada diri siswa berbeda satu sama lain.

3. Sikap Disiplin
Nilai sikap displin pada aspek yang diamati observer selama proses pembelajaran yaitu masuk kelas tepat waktu, mengumpulkan tugas, mengerjakan tugas, dan membawa buku pelajaran selama proses pembelajaran sangat tinggi dilihat dari rata-rata persentase yang diperoleh siswa yaitu $81 \%$ sehingga dapat disimpulkan bahwa sikap displin yang ada pada setiap individu menunjukkan kedisplinan mereka baik.

4. Sikap bekerja sama

Nilai sikap bekerjasama pada aspek yang diamati observer selama proses pembelajaran yaitu aktif dalam kerja kelompok, suka menolong teman, kesediaan melakukan tugas sesuai kesepakatan dan rela berkorban demi teman selama proses pembelajaran cukup dilihat dari rata-rata persentase yang diperoleh siswa yaitu $70 \%$ sehingga dapat disimpulkan sikap bekerja sama yang ada pada setiap individu menunjukkan jiwa bekerja sama mereka yang baik

5. Sikap keaktifan

Nilai sikap keaktifan pada aspek yang diamati observer selama proses pembelajaran yaitu aktif dalam memberikan pertanyaan, aktif memberikan pendapat yang berbeda, memberikan masukan dan kritikan pada saat diskusi kelompok, dan sering menanggapi pertanyaan atau pernyataan sangat tinggi dilihat dari rata-rata persentase yang diperoleh siswa yaitu $60 \%$ sehingga dapat disimpulkan sikap keaktifan yang ada pada setiap individu menunjukkan keaktifan mereka yang masih kurang dalam proses pembelajaran.

Dengan aspek ini observer bisa menilai sikap siswa termasuk sikap yang baik atau sikap yang buruk. Sikap menerima menunjukkan subjek mau dan memperhatikan stimulus yang diberikan objek. Hal ini terlihat ketika dalam proses kegiatan belajar dikelas seperti siswa yang memperhatikan dan mendengarkan dengan baik ketika guru memberikan penjelasan mengenai materi yang disampaikan. Tetapi ini tidak hanya berlaku ketika sedang berada dikelas saja. Informasi atau penjelasan tentang berbagai hal yang bisa kita dapatkan dari mana saja dan dari siapa saja selama informasi tersebut merupakan hal yang baik. 
Dari kelima indikator penilaian sikap tersebut yaitu sikap menghargai, sikap displin, sikap bekerjasama, sikap tanggung jawab dan sikap keaktifan terlihat bahwa terbentuk dari pengalaman pribadi siswa. Sesuai dengan pendapat Azwar (2011) bahwa salah satu faktor yang mempengaruhi sikap adalah pengalaman pribadi. Pengalaman pribadi dapat menjadi dasar pembentukan siakp apabila pengalaman pribadi tersebut meninggalkan kesan yang kuat. Sikap akan lebih mudah terbentuk apabila pengalaman pribadi tersebut melibatkan faktor emosional. Sikap inilah yang membuat siswa bereaksi terhadap situasi serta menentukan apa yang dicari oleh siwa.

Pada sikap terdapat gambaran bagaimana seharusnya bersikap dalam belajar, menanggapi suatu permasalahan, melaksanakan tugas dan mengembangkan diri. Hal ini tentunya sangat mempengaruhi pengetahuan siswa kearah yang positif. Kurangnya sikap positif dalam belajar dapat menyebabkan rendahnya pengetahuan siswa. Melalui penanaman sikap dalam pembelajaran maka dapat belajar dan menemukannya. Sikap yang harus dimiliki oleh siswa dalam menunjang pengetahuannya yaitu: disiplin, tanggung jawab, bekerja sama, menghormati, dan aktif dalam pembelajaran (Tasdemir, 2013). Salah satu yang diupayakan untuk meningkatkan belajar siswa di SMA Negeri 1 Tanjung morawa dengan menumbuhkan dan menanamkan sikap yang positif terhadap materi pembelajaram sistem reproduksi manusia.

\section{DAFTAR PUSTAKA}

Azwar, S., (2007). Sikap Manusia, Teori dan Pengukurannya, Penerbit Erlangga, Jakarta.

Arikunto, S., (2009). Dasar-Dasar Evaluasi Pendidikan, Rineka Cipta, Jakarta.

Fadli, (2015), Hubungan Antara Pengetahuan dan Sikap Siswa Tentang Materi Sistem Reproduksi di SMA Negeri 1 Tawangsari Sukaharjo, Jurnal Ilmiah Kesehatan. Vol 1(5). Halaman 15-17.

Febry,V., Nirwana, H., Nurfanah., (2012), Pemahaman Siswa Mengenai Kesehatan Reproduksi Remaja
Melalui Layanan Informasi, Jurnal IImiah Konseling Vol 1(1), Halaman 3-5.

Hamzah, (2008). Guru Pofesional . PT Grafindo Persada, Jakarta.

Maryanti ,D., (2009), Kesehatan Reproduksi Teori Dan Praktikum, Nuha Medica Yogyakarta.

Maolinda, N., Sriati, A., Maryati, I., (2008), Hubungan Pengetahuan Dengan Sikap Siswa Terhadap Pendidikan Kesehatan Reproduksi Remaja Di SMAN 1 Margahayu. Vol 1(3) Halaman 2-4.

Tasdemir, (2013). Pengaruh Sikap Siswa Terhadap Hasil Belajar, Citra Aditya Bakti, Bandung. 